\title{
Tight bounds on missing late veneer in early Archean peridotite from triple oxygen isotopes
}

\author{
S.T.M. Peters ${ }^{1 *}$, M.B. Fischer ${ }^{1,2}$, A. Pack ${ }^{1}$, K. Szilas $^{3}$, P.W.U. Appel ${ }^{4}$, \\ C. Münker ${ }^{5}$, L. Dallai' ${ }^{6}$, C.S. Marien ${ }^{5}$
}

Abstract

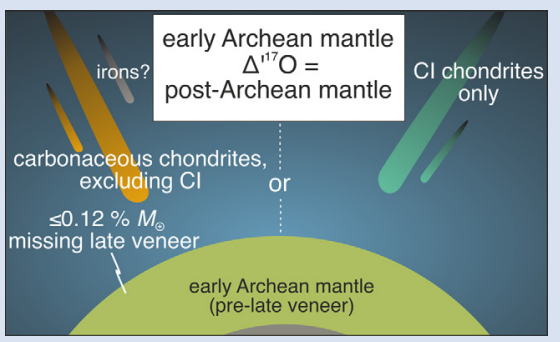

Oxygen isotopes provide a unique possibility to study Earth's late accretion phase from a lithophile element perspective, because most carbonaceous chondrites meteorites that likely resemble the composition of the terrestrial late veneer - have markedly different $\Delta^{\prime 17} \mathrm{O}$ values than the silicate Earth. Ultramafic rocks in the early Archean assemblage of southwest Greenland have not incorporated the full amount of late accreted materials, and therefore possibly record the $\Delta^{\prime 17} \mathrm{O}$ of the mantle before late accretion. We measured ${ }^{17} \mathrm{O} /{ }^{16} \mathrm{O}$ and ${ }^{18} \mathrm{O} /{ }^{16} \mathrm{O}$ ratios of olivine from these ultramafic rocks and compared them with olivine from post-Archean mantle peridotite. A missing late veneer component was not resolved. The missing component from the early Archean mantle is therefore restricted to $\leq 0.12 \%$ of Earth's mass $\left(M_{\oplus}\right)$ for most carbonaceous chondrite-like materials, unless the missing component resembles CI chondrites - the only carbonaceous chondrites with $\Delta^{\prime 17} \mathrm{O}$ values similar to those of the silicate Earth. If the early Archean mantle had incorporated $60 \%$ late veneer, the overall late accreted mass would be restricted to $\leq 0.3 \% M_{\oplus}$ for most types of carbonaceous chondrites, with a more massive late veneer only possible for CI-like chondrites.

Received 7 March 2021 | Accepted 18 June 2021 | Published 1 September 2021

\section{Introduction}

Missing late veneer in early Archean mantle domains. Earth formed by the accretion of rocky materials in a protoplanetary disk. The final $\sim 0.5 \%$ of these materials escaped metal-silicate equilibrium during core formation processes, and are commonly referred to as the late veneer (Walker, 2009). The composition of these late accreted materials is interesting to study, because they possibly contributed a large portion of volatile elements and water to the Earth's mass (Wang and Becker, 2013; Braukmüller et al., 2019).

Based on platinum and tungsten isotope work, it was proposed that some Archean mantle domains did not incorporate the full amount of late veneer (e.g., Willbold et al., 2011; Creech et al., 2017). Such mantle domains could then provide unique windows into the final stages of Earth's accretion and its earliest evolution. An unambiguous pre-late veneer signal is present in ultramafic enclaves that are entrained in the Eoarchean Itsaq Gneiss Complex and Mesoarchean Fiskefjord region of southwest Greenland. These rocks show a uniform excess in s-process Ru nuclides compared to r-process $\mathrm{Ru}$ nuclides relative to the bulk silicate Earth (Fischer-Gödde et al., 2020). The excess s-process $\mathrm{Ru}$ in the ultramafic enclaves is best explained by a deficit in late accreted materials that carried a deficit in s-process Ru. Whereas both carbonaceous and non-carbonaceous chondrite groups carry deficits in s-process $\mathrm{Ru}$, the s-process deficit is only sufficiently large in carbonaceous chondrite groups to potentially account for the observed s-process excess in the ultramafic enclaves, given the concentrations of platinum group elements in the Eoarchean mantle (Fischer-Gödde et al., 2020). This conclusion is important, because it would support a volatile-rich, carbonaceous chondrite-like late veneer, and therewith complement evidence from volatile chalcophile elements in the postArchean mantle (Wang and Becker, 2013; Braukmüller et al., 2019; Varas-Reus et al., 2019).

Potential of studying triple oxygen isotope ratios. Oxygen stable isotope ratios $\left({ }^{17} \mathrm{O} /{ }^{16} \mathrm{O},{ }^{18} \mathrm{O} /{ }^{16} \mathrm{O}\right)$ are a unique tool for studying late accretion processes from a lithophile element perspective (Rumble et al., 2013; Valley et al., 2014; Young et al., 2016; Reimink et al., 2018), because bulk asteroids in the Solar System show $\sim 6000 \mathrm{ppm}$ variations in $\Delta^{\prime 17} \mathrm{O}$ (Clayton, 1993). This is large compared to the $\sim 5 \mathrm{ppm}$ analytical resolution of state of the art laser fluorination techniques. Henceforth, we use a definition for $\Delta^{\prime 17} \mathrm{O}$ with:

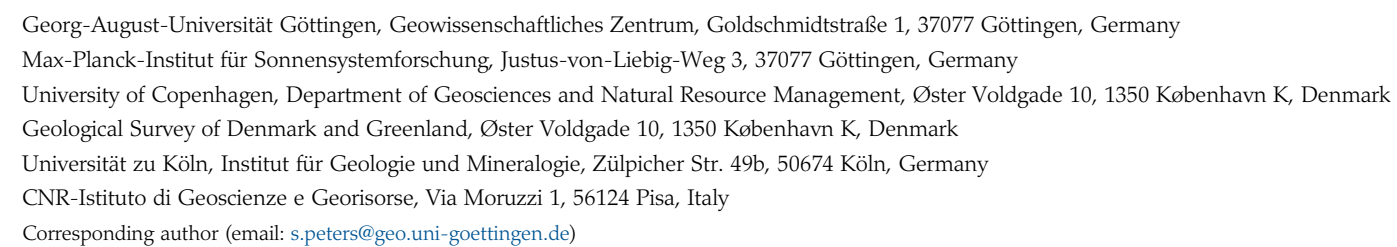




$$
\begin{aligned}
& \Delta^{\prime}{ }^{17} \mathrm{O} \\
& \quad=1000\left[1000 \ln \left(\frac{\delta^{17} \mathrm{O}}{1000}+1\right)-0.528 \times 1000 \ln \left(\frac{\delta^{18} \mathrm{O}}{1000}+1\right)\right]
\end{aligned}
$$

Carbonaceous chondrites have lower $\Delta^{\prime 17} \mathrm{O}$ values than the silicate Earth, with only $\mathrm{CI}$ chondrites having similar but slightly higher $\Delta^{\prime 17} \mathrm{O}$ and much higher $\delta^{18} \mathrm{O}$ values than the silicate Earth (Clayton, 1993). If the early Archean ultramafic enclaves from southwest Greenland would have been deprived of a late veneer component that resembles most carbonaceous chondrite types ( $\mathrm{CM}, \mathrm{CV}, \mathrm{CO}, \mathrm{CK}, \mathrm{CR}, \mathrm{CH}, \mathrm{CB}$ chondrites), samples from the early Archean ultramafic enclaves would therefore be expected to have an elevated $\Delta^{\prime 17} \mathrm{O}$ compared to the silicate Earth. Only if the ultramafic enclaves would be missing a late veneer component that resembles CI chondrites, would they have a similar or lower $\Delta^{\prime 17} \mathrm{O}$ than the silicate Earth. In order to study mass and composition of the missing late veneer component from the early Archean ultramafic enclaves of southwest Greenland, we therefore compared their olivine $\Delta^{\prime 17} \mathrm{O}$ values with olivine in post-Archean mantle peridotite.

\section{Samples and Methods}

The suite of post-Archean mantle peridotite sample comprises 14 lherzolithic xenoliths that were erupted in Phanerozoic magmas from diverse geological settings, and 1 dunite sample from the Beni Boussera massif (Supplementary Information S-1). The ultramafic enclaves with s-process Ru excess (Fischer-Gödde et al., 2020) that we studied are from two localities within the $>3.7 \mathrm{Ga}$ Isua supracrustal belt (ISB), one locality south of the Isua supracrustal belt (SOISB), the $\sim 3.8$ Ga Narssaq ultramafic body (NUB), and the 3.8 Ga Ujaragssuit Nunât ultramafic body (Supplementary Information S-1). The early Archean ultramafic bodies were interpreted either as slivers of residual mantle peridotite, as metamorphosed cumulates from (ultra)mafic magmas, or, for one location, as an ultramafic layered intrusion. We also studied peridotite samples from the Fiskefjord region that are geologically related to the Mesoarchean Seqi peridotite body (Szilas et al., 2015), for which an excess in s-process Ru compared to the silicate Earth was also reported (Fischer-Gödde et al., 2020). Olivine samples were analysed for their triple oxygen isotope compositions $\left(\delta^{17} \mathrm{O}, \delta^{18} \mathrm{O}\right)$ using laser assisted fluorination protocols (Supplementary Information S-2). All samples were analysed relative to San Carlos olivine, which is considered here to have a $\Delta^{\prime 17} \mathrm{O}=-51.8 \mathrm{ppm}$ relative to VSMOW.

\section{Results}

Olivine $\delta^{18} \mathrm{O}$ values of the post-Archean mantle peridotite samples are on average $\delta^{18} \mathrm{O}=5.21 \pm 0.08 \%$ o ( 1 s.d., $\left.n=15\right)$, which is in good agreement with previous data for olivine in mantle peridotite (e.g., Mattey et al., 1994) (Table S-1). The post-Archean mantle peridotite samples have an average olivine $\Delta^{\prime 17} \mathrm{O}$ value of $-51.6 \pm 2.1 \mathrm{ppm}$ ( 1 s.d., $n=15$; Fig. 1a), which is in line with data for mafic and ultramafic rocks from previous studies (Herwartz et al., 2014; Greenwood et al., 2018; Cano et al., 2020). No variations in olivine $\Delta^{\prime 17} \mathrm{O}$ values were found for the post-Archean mantle peridotite samples. The peridotite samples from the Archean ultramafic enclaves in the Itsaq Gneiss Complex and Fiskefjord region show a much wider range in olivine $\delta^{18} \mathrm{O}$ values $\left(\delta^{18} \mathrm{O}=2.8-6.2 \%\right.$ ) (Table S-2). Olivine $\Delta^{\prime 17} \mathrm{O}$ values of the early Archean ultramafic bodies are on average $\Delta^{\prime 17} \mathrm{O}=-50.9 \pm 3.2$ ppm ( 1 s.d., $n=23$ ), a value that is
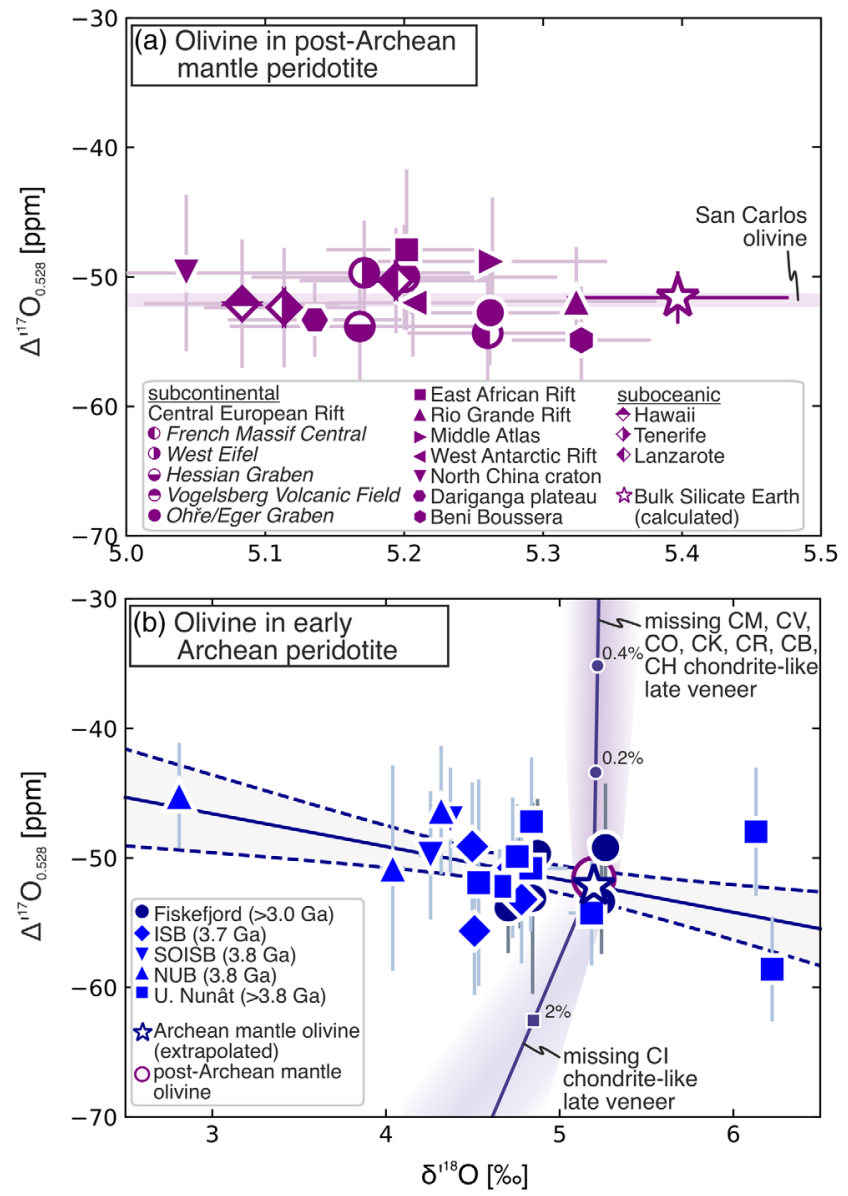

Figure 1 Plots of $\Delta^{\prime 17} \mathrm{O}$ vs. $\delta^{\prime 18} \mathrm{O}( \pm 1$ s.e.m.) of olivine from ultramafic rocks. (a) Olivine in peridotites that were erupted as xenoliths in Phanerozoic magmas and from the Beni Boussera massif, relative to the composition of San Carlos olivine (horizontal line, $\Delta^{\prime 17} \mathrm{O}=-51.8 \mathrm{ppm} ;$ Supplementary Information S-2). The composition of the bulk silicate Earth (star) is calculated from the mean olivine compositions from this study \pm 1 s.d. and is based on $-0.2 \%$ fractionation in $\delta^{18} \mathrm{O}$ and a $\theta$ value of 0.53 for fractionation between olivine and bulk peridotite. (b) Olivine from early Archean ultramafic enclaves with excess s-process Ru (FischerGödde et al., 2020). The curve corresponds to a linear fit \pm 1 s.d. through the Archean peridotite data in $\delta^{17} O$ versus $\delta^{18} O$ space and is used to extrapolate the compositions of the samples, which were in part altered by fluid-rock reactions, to the $\Delta^{\prime 17} \mathrm{O}$ of pristine olivine in the early Archean mantle with $\delta^{18} \mathrm{O}=5.21 \%$ (star). Shadowed fields correspond to calculated olivine compositions if carbonaceous chondrites would be missing from the ultramafic enclaves, considering all carbonaceous chondrite meteorites for which data are available in the Meteoritical Bulletin Database as possible end member compositions for the late veneer (Table S-3). Curves are shown for missing late veneer with the average composition of $\mathrm{CM}, \mathrm{CV}, \mathrm{CO}, \mathrm{CK}, \mathrm{CR}, \mathrm{CH}, \mathrm{CB}$ chondrites and the average composition of $\mathrm{Cl}$ chondrites, respectively, with the percentages of missing late veneer indicated relative to the mass of the Earth.

indistinguishable from the $\Delta^{\prime 17} \mathrm{O}$ value of post-Archean mantle olivine. The early Archean peridotite samples show decreasing olivine $\Delta^{\prime 17} \mathrm{O}$ values with increasing $\delta^{18} \mathrm{O}$ values (Fig. $1 \mathrm{~b}$ ).

\section{Discussion}

Effects of fluid-rock reactions. Olivine $\delta^{18} \mathrm{O}$ values of the early Archean peridotites predominantly deviate towards lower values 
compared to post-Archean mantle olivine. We reported similarly low and variable olivine $\delta^{18} \mathrm{O}$ values for a $>2.7$ Ga peridotite body that is entrained in the Kuummiut terrane in southeast Greenland, for which the low and variable $\delta^{18} \mathrm{O}$ values reflect the effects of fluid-rock reactions that were followed by dehydration of the peridotitic protoliths at high grade metamorphic conditions (Peters et al., 2020). Likewise, we suggest that the ultramafic enclaves in the Itsaq Gneiss Complex and Fiskefjord region experienced hydration and dehydration events during their metamorphic history that modified their primary olivine $\delta^{18} \mathrm{O}$ values, a process that is likely common for ultramafic rocks in Archean high grade metamorphic terranes (Nishio et al., 2019) (Supplementary Information S-1). Fluid-rock reactions cannot only have shifted the $\delta^{18} \mathrm{O}$ values of the Archean peridotite samples, but may also have altered the $\Delta^{\prime 17} \mathrm{O}$ values of the peridotite samples (e.g., Sengupta and Pack, 2018). In order to obtain the $\Delta^{\prime 17} \mathrm{O}$ value of pristine olivine in the ultramafic rocks before they interacted with fluids, we extrapolated the measured $\Delta^{\prime 17} \mathrm{O}$ values to the $\delta^{18} \mathrm{O}$ value of typical mantle olivine (this study; $\delta^{18} \mathrm{O}=5.21 \%$ ) (Fig. 1b). The extrapolated $\Delta^{\prime 17} \mathrm{O}$ value of pristine olivine in the early Archean mantle is $-52.3 \pm 1.7 \mathrm{ppm}$ ( 1 s.d.); a value that is only $1.4 \mathrm{ppm}$ lower than the average $\Delta^{\prime 17} \mathrm{O}$ of the uncorrected data.

Implications for missing late veneer. The suggested $\Delta^{\prime 17} \mathrm{O}$ value of pristine olivine in the early Archean ultramafic rocks is indistinguishable from the mean $\Delta^{\prime 17} \mathrm{O}$ value of olivine in postArchean mantle peridotite (Fig. 1b). A pre-late veneer signal in the Archean ultramafic enclaves is thus not resolved with respect to oxygen isotopes. This conclusion corroborates earlier results from a laser fluorination study on the Acasta Gneiss Complex and Isua supracrustal belt (Rumble et al., 2013), and lower resolution SIMS data for the Jack Hills zircons, as well as zircons from the Acasta Gneiss Complex and (Valley et al., 2014; Reimink et al., 2018). Using the new data, we calculated the uppermost likely limits for missing late veneer from the Itsaq Gneiss Complex and Fiskefjord mantle, assuming the compositions of carbonaceous chondrite groups as the missing components (c.f. Fischer-Gödde et al., 2020). In general, and by definition, the compositions of the mantle before the late veneer (hereafter 'pre-late veneer mantle'; PLVM), the bulk silicate Earth and the late veneer plot on a mixing line in $\delta^{17} \mathrm{O}$ versus $\delta^{18} \mathrm{O}$ space. The slope $m$ and intercept $i$ of this mixing line are given by the $\delta^{17} \mathrm{O}$ and $\delta^{18} \mathrm{O}$ values of the bulk silicate Earth and the composition of the late veneer. In $\delta^{\prime 17} \mathrm{O}$ versus $\delta^{\prime 18} \mathrm{O}$ space, the composition of the pre-late veneer mantle also plots on a line with slope 0.528 and intercept $\Delta^{\prime 17} \mathrm{O}$ that equals the value for the pre-late veneer mantle. The point of intersection of the two relations in $\delta^{\prime 17} \mathrm{O}$ versus $\delta^{\prime 18} \mathrm{O}$ space is given by:

$$
\begin{aligned}
& 0.528 \delta^{\prime 18} \mathrm{O}_{\text {PLVM }}+\frac{\Delta^{\prime 17} \mathrm{O}_{\text {PLVM }}}{1000} \\
& =1000 \ln \left[m e^{\frac{\delta^{\prime} 188_{\mathrm{OPLV}}}{1000}}-m+\frac{i}{1000}+1\right]
\end{aligned}
$$

and can be approximated with the Newton-Raphson method. The intersection $\delta$ values then allow determining the oxygen atom fraction of missing late veneer from the pre-late veneer mantle (Supplementary Information S-4).

Based on Equation 2 we modelled possible masses of missing late veneer if carbonaceous chondrite groups would be missing from the Itsaq Gneiss Complex and Fiskefjord mantle, using a Monte Carlo approach (Fig. 2). In each Monte Carlo run, the end member composition of the late veneer was selected by randomly sampling a meteorite composition from the carbonaceous chondrite groups of interest, i.e. each meteorite specimen from a given selection of carbonaceous chondrites was
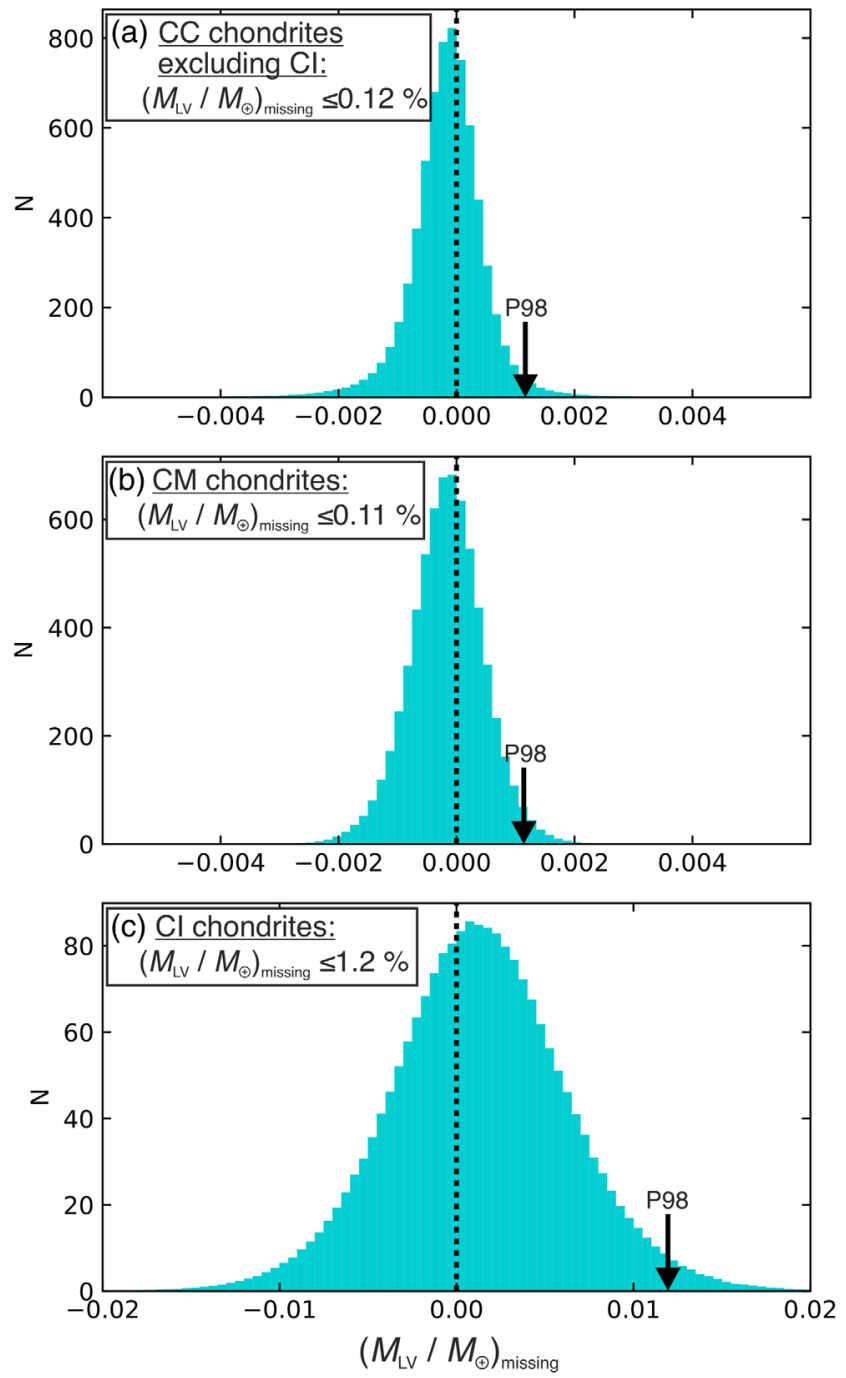

Figure 2 Missing late veneer from the Itsaq Gneiss Complex and Fiskefjord mantle relative to the mass of the Earth, $\left(M_{\mathrm{LV}} / M_{\oplus}\right)_{\text {missing, }}$ calculated from the data in this study and from available triple oxygen isotope data for carbonaceous chondrites (Monte Carlo simulation; $10^{6}$ runs). End member compositions of the late veneer were sampled randomly for given chondrite groups from a compilation of all meteorite data that are available in the Meteoritical Bulletin Database (Table S-3). The $\delta^{18} \mathrm{O}$ value of the silicate Earth was considered to be $0.2 \%$ higher than olivine in mantle peridotite from this study, i.e. $\delta^{18} \mathrm{O}_{\mathrm{BSE}}=5.41 \%$. The $97.72^{\text {nd }}$ percentile (P98) of the outcomes are shown by arrows and are given in the panel headings as percentages; and are considered uppermost bounds for missing late veneer. Outcomes with negative values correspond to hypothetical scenarios in which the Itsaq Gneiss Complex and Fiskefjord mantle contain excess late veneer. Dotted lines show outcomes where $\left(M_{\mathrm{LV}} / M_{\oplus}\right)_{\text {missing }}=0$. (a) Missing carbonaceous chondrites, excluding $\mathrm{Cl}$ chondrites. (b) Missing CM chondrites only. (c) Missing Cl chondrites only.

considered equally likely to represent a possible end member composition of the late veneer (Table S-3). We adopted concentrations in the mixing calculations of 46.5 wt. \% oxygen in carbonaceous chondrites and $44.33 \mathrm{wt}$. \% oxygen in the terrestrial mantle (Palme and $\mathrm{O}^{\prime} \mathrm{Neill}, 2003$ ). In the simulations, the $\Delta^{\prime 17} \mathrm{O}$ values for the bulk silicate Earth and the pre-late veneer mantle were sampled from normally distributed populations that are described by the mean values and standard deviations for post-Archean mantle peridotite and the extrapolated $\Delta^{\prime 17} \mathrm{O}$ value for pristine olivine in early Archean peridotite from this 
study, respectively. We consider the $97.72^{\text {nd }}$ percentile of the outcomes of the simulations as the uppermost likely values for the missing late veneer. These uppermost values correspond to a missing late veneer component relative to the Earth's mass $\left(M_{\oplus}\right)$ of $\leq 0.12 \% M_{\oplus}$ if the missing component would resemble $\mathrm{CM}, \mathrm{CV}, \mathrm{CO}, \mathrm{CK}, \mathrm{CR}, \mathrm{CH}, \mathrm{CB}$, but not $\mathrm{CI}$ chondrites (Fig. 2a); $\leq 0.11 \% M_{\oplus}$ if the missing component would resemble only $\mathrm{CM}$ chondrites (Fig. 2 b); and $\leq 1.2 \% M_{\oplus}$ if the missing component would resemble CI chondrites (Fig. 2c).

Our modelling results have implications for the materials that comprised Earth's late veneer. Fischer-Gödde et al. (2020) estimated based on their $\mathrm{Ru}$ isotope data that a late veneer component of up to $0.3 \% M_{\oplus}$ of carbonaceous chondrite-like materials could be missing from the Itsaq Gneiss Complex and Fiskefjord mantle, and favoured $\mathrm{CM}$ chondrites as the missing component. The oxygen isotope data, in contrast, imply that only a much smaller component of carbonaceous chondrites $\left(\leq 0.12 \% M_{\oplus}\right)$ can possibly be missing from the early Archean ultramafic enclaves with respect to oxygen, unless this component comprises CI chondrites. We propose two end member scenarios that best reconcile the triple oxygen isotope data with the available Ru isotope data. In one end member scenario, the missing late veneer component indeed resembles $\mathrm{CM}$ chondrites with the equivalent mass of $\leq 0.11 \% M_{\oplus}$ (Fig. 2b). This scenario implies that the early Archean mantle had incorporated more than $c a .>86 \%$ late veneer with respect to lithophile elements, which agrees with some estimates from the concentrations of highly siderophile elements in the early Archean mantle (van de Löcht et al., 2018), but not with others (Dale et al., 2017). The missing CM chondrite-like component was possibly complemented by a missing component of carbonaceous group iron meteorite-like materials, e.g., materials similar to the IID and IVA irons that have comparable Ru isotope compositions compared to carbonaceous chondrites (Fischer-Gödde and Kleine, 2017) and high Ru concentrations, but are deficient in $\mathrm{O}$. This scenario is also consistent with highly siderophile element concentrations and ${ }^{187} \mathrm{Os} /{ }^{188} \mathrm{Os}$ ratios in lunar impact rocks and in the upper mantle (Fischer-Gödde and Becker, 2012). In the second end member scenario, the missing late veneer component resembles the composition of $\mathrm{CI}$ chondrites (Fig. 2c). This scenario is feasible only if the s-process Ru deficit in $\mathrm{CI}$ chondrites is greater than was considered in the modelling by Fischer-Gödde et al. (2020). We consider this a reasonable suggestion, because the $\mathrm{Ru}$ isotope composition of $\mathrm{CI}$ chondrites is constrained at present by a single meteorite specimen only, whereas other carbonaceous chondrite groups show internal $\mathrm{Ru}$ isotope variations (Fischer-Gödde and Kleine, 2017).

The discussion of our data thus far concerns the mass and composition of a late veneer component that can possibly be missing from the early Archean mantle. It can be assumed instead that the early Archean mantle was deficient in $40 \%$ late accreted materials (Dale et al., 2017). Following this line of logic, the triple oxygen isotope data imply a maximum late accreted mass of $\leq 0.3 \% M_{\oplus}$ for $\mathrm{CM}, \mathrm{CV}, \mathrm{CO}, \mathrm{CK}, \mathrm{CR}, \mathrm{CH}, \mathrm{CB}$ chondrites; and $\leq 3 \% M_{\oplus}$ CI chondrites. In conjunction with the absolute concentrations of highly siderophile elements in the post-Archean mantle, this conclusion would imply that the late veneer contained abundant CI-like materials; a scenario that agrees well with volatile element patterns (Braukmüller et al., 2019) and the Se isotope composition of the post-Archean mantle (Varas-Reus et al., 2019).

\section{Acknowledgements}

We thank Jesse Reimink and an anonymous reviewer for constructive feedback on the manuscript, and Helen Williams for editorial handling. Some of the post-Archean peridotite samples were collected in the field by Gerhard Wörner, Tsegaye Abebe Adhana, Qunke Xia, and Yuliya Kochergina. KS acknowledges grant CF18-0090 from the Carlsberg Foundation for field work; CM and CMA acknowledge funding by DFG project Mu 1406/18 within SPP 1833

\section{Editor: Helen Williams}

\section{Additional Information}

Supplementary Information accompanies this letter at https:// www.geochemicalperspectivesletters.org/article2120.

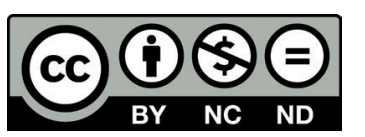

(C) 2021 The Authors. This work is distributed under the Creative Commons Attribution NonCommercial No-Derivatives 4.0 License, which permits unrestricted distribution provided the original author and source are credited. The material may not be adapted (remixed, transformed or built upon) or used for commercial purposes without written permission from the author. Additional information is available at https://www. geochemicalperspectivesletters.org/copyright-and-permissions.

Cite this letter as: Peters, S.T.M., Fischer, M.B., Pack, A., Szilas, K., Appel, P.W.U., Münker, C., Dallai, L., Marien, C.S. (2021) Tight bounds on missing late veneer in early Archean peridotite from triple oxygen isotopes. Geochem. Persp. Let. 18, 27-31.

\section{References}

BraukmÜller, N., WOMBaCher, F., FunK, C., MÜNKER, C. (2019) Earth's volatile element depletion pattern inherited from a carbonaceous chondrite-like source. Nature Geoscience 12, 564-568.

CAno, E.J., SharP, Z.D., ShEARER, C.K. (2020) Distinct oxygen isotope compositions of the Earth and Moon. Nature Geoscience 13, 270-274.

Clayton, R.N. (1993) Oxygen isotopes in meteorites. Annual Review of Earth and Planetary Sciences 21, 115-149.

Creech, J.B., Baker, J.A., Handler, M.R., Lorand, J.P., Storey, M., Wainwright, A.N., Luguet, A., Moynier, F., Bizzarro, M. (2017) Late accretion history of the terrestrial planets inferred from platinum stable isotopes. Geochemical Perspectives Letters 3, 94-104.

Dale, C.W., Kruijer, T.S., Burton, K.W. (2017) Highly siderophile element and ${ }^{182}$ W evidence for a partial late veneer in the source of 3.8 Ga rocks from Isua, Greenland. Earth and Planetary Science Letters 458, 394-404.

FISCHER-GÖDDE, M., BECKER, H. (2012) Osmium isotope and highly siderophile element constraints on ages and nature of meteoritic components in ancient lunar impact rocks. Geochimica et Cosmochimica Acta 77, 135-156.

Fischer-GÖDDE, M., KLeINE, T. (2017) Ruthenium isotopic evidence for an inner Solar System origin of the late veneer. Nature 541, 525-527.

Fischer-Gödde, M., Elfers, B.M., MünKer, C., Szilas, K., Maier, W.D., Messling, N., Morishita, T., VAn KRANENDONK, M., Smithies, H. (2020) Ruthenium isotope vestige of Earth's pre-late-veneer mantle preserved in Archaean rocks. Nature 579, 240-244.

Greenwood, R.C., Barrat, J.A., Miller, M.F., Anand, M., Dauphas, N., Franchi, I.A. Sillard, P., StARKEY, N.A. (2018) Oxygen isotopic evidence for accretion of Earth's water before a high-energy Moon-forming giant impact. Science Advances 4, 5928.

Herwartz, D., PACK, A., Friedrichs, B., Bischoff, A. (2014) Identification of the giant impactor Theia in lunar rocks. Science 344, 1146-1150.

Mattey, D., Lowry, D., Macpherson, C. (1994) Oxygen isotope composition of mantle peridotite. Earth and Planetary Science Letters 128, 231-241.

Nishio, I., Morishita, T., Szilas, K., Pearson, G., Tani, K.I., Tamura, A., Harigane, Y., Guotana, J.M. (2019) Titanian clinohumite-bearing peridotite from the ulamertoq ultramafic body in the 3.0 Ga akia terrane of southern west Greenland. Geosciences 9, 153.

Palme, H., O'Neill, H. (2003) 2.01 - Cosmochemical estimates of mantle composition. In: Holland, H.D., Turekian, K.K. (Eds.) Treatise on Geochemistry. First Edition, Elsevier, Oxford. 1-38. 
Peters, S.T.M., Szillas, K., Sengupta, S., Kirkland, C.L., Garbe-Schönberg, D., PACK, A. (2020) >2.7 Ga metamorphic peridotites from southeast Greenland record the oxygen isotope composition of Archean seawater. Earth and Planetary Science Letters 544, 116331.

Reimink, J.R., Chacko, T., Carlson, R.W., Shirey, S.B., Liu, J., Stern, R.A., Bauer, A.M., Pearson, D.G., Heaman, L.M. (2018) Petrogenesis and tectonics of the Acasta Gneiss Complex derived from integrated petrology and ${ }^{142} \mathrm{Nd}$ and ${ }^{182} \mathrm{~W}$ extinct nuclide-geochemistry. Earth and Planetary Science Letters 494, 12-22.

Rumble, D., Bowring, S., IzUuka, T., Komiya, T., Lepland, A., Rosing, M.T., Ueno, Y. (2013) The oxygen isotope composition of earth's oldest rocks and evidence of a terrestrial magma ocean. Geochemistry, Geophysics, Geosystems 14, 1929-1939.

Sengupta, S., Pack, A. (2018) Triple oxygen isotope mass balance for the Earth's oceans with application to Archean cherts. Chemical Geology 495, 18-26.

Szilas, K., Kelemen, P.B., Bernstein, S. (2015) Peridotite enclaves hosted by Mesoarchaean TTG-suite orthogneisses in the Fiskefjord region of southern West Greenland. GeoResJ 7, 22-34.

Valley, J.W., CAvosie, A.J., Ushikubo, T., Reinhard, D.A., Lahrence, D.F., Larson, D.J., Clifton, P.H., Kelly, T.F., Wilde, S.A., Moser, D.E., Sificuzza, M.J. (2014) Hadean age for a post-magma-ocean zircon confirmed by atomprobe tomography. Nature Geoscience 7, 219-223.

van de Löcht, J., Hoffmann, J.E., Li, C., Wang, Z., Becker, H., Rosing, M.T KLEINSCHRODT, R., MÜNKER, C. (2018) Earth's oldest mantle peridotites show entire record of late accretion. Geology 46, 199-202.

Varas-Reus, M.I., König, S., Yierpan, A., Lorand, J.P., SchoenberG, R. (2019) Selenium isotopes as tracers of a late volatile contribution to Earth from the outer Solar System. Nature Geoscience 12, 779-782.

WALKER, R.J. (2009) Highly siderophile elements in the Earth, Moon and Mars Update and implications for planetary accretion and differentiation. Chemie der Erde 69, 101-125.

WANG, Z., BECKER, H. (2013) Ratios of S, Se and Te in the silicate Earth require a volatile-rich late veneer. Nature 499, 328-331.

Willbold, M., Elliott, T., Moorbath, S. (2011) The tungsten isotopic composition of the Earth's mantle before the terminal bombardment. Nature 477 195-198.

Young, E.D., Kohl, I.E., Warren, P.H., Rubie, D.C., Jacobson, S.A., Morbidelli, A (2016) Oxygen isotopic evidence for vigorous mixing during the Moonforming giant impact. Science 351, 493-496. 